\title{
Public Registries as Tools for Realising the Swedish Welfare State - Can the State still Be Trusted?
}

\author{
Jane Reichel*®, Johanna Chamberlain** \\ * Professor in Administrative Law, Stockholm University, Faculty of Law, e-mail: jane.reichel@ \\ juridicum.su.se \\ ** Post doc, Uppsala University, Department of Business Studies, e-mail: johanna.chamberlain@ \\ fek.uu.se
}

\begin{abstract}
Sweden has a long tradition of transparency and keeping public archives and registries for the benefit of the society at large. Access to comprehensive public information, including registries containing individualised data, has been an integral part in the building of the Swedish welfare state. An important explanatory factor for its acceptance is the high level of social trust in the Swedish society, in that citizens to a large extent trust each other, the government and the public authorities and other institutions in the society. Over the last few decades, changes have taken place connected to digitalisation of the society and an increased awareness of the possible privacy intrusion that may follow. A number of Swedish "register scandals" have been unearthed in media, involving both private and public entities. In order to protect the Swedish cultural heritage of accessible archives and public information and retain social trust, the Swedish legislator should carefully balance the interest in transparency against the right to privacy and data protection following the case law of the European Court of Human Rights and EU law.
\end{abstract}

Keywords: transparency, registries, archives, privacy, data protection, social trust, freedom of the press

\section{Introduction: The function of information in the welfare state}

Sweden has a long tradition of keeping public registries for the benefit of the society at large. Access to comprehensive public information has been an integral part in the building of the welfare state. The unique and comprehensive system of personal identity numbers and public registries that started with "church books" of the population in the $17^{\text {th }}$ century has, for many decades, made important research possible, for example in the medical field. ${ }^{1}$ The fact that this immense web of information once could be established goes back on several different factors. One is the long tradition of openness, dating back to 1766 , when the world's first right to access of official documents was introduced in

1 SCB webpage, History of Statistics in Sweden, www.scb.se/en/About-us/main-activity/history-of-statisticssweden/ 
Swedish law. Swedes are thus used to having access to public information - including personal information on identifiable persons. Another factor is the high level of trust from Swedish citizens from the mid-20 th century regarding the expanding welfare state. In the era of social engineering, stately collection and treatment of personal data was not seen as a threat but rather as a necessity (Abrahamsson, 2006, p. 413; Axberger, 2020, p. 763-770).

A third, more technically oriented factor is the usableness of the information due to the personal identity number all residents in Sweden have. From 1947 and onwards, all individuals listed as living in Sweden have been given a unique personal identity number (PIN), which is used both in relation to public authorities and in countless other situations. ${ }^{2}$ This means that the identification numbers open the door to a vast amount of personal information - something that would in many countries be seen as risky and intrusive. However, and in accordance with the strong tradition of openness and trust, at the dawn of the PIN era, the attitude amongst the Swedes was that the personal information was required in order for the state to plan the construction of accommodation, education, health care and all the other components that would secure a high and even standard of living for the growing, modern population. A number of authorities, departments and institutions have had key roles in the administration of the welfare state - the most significant being Statistics Sweden (SCB), launched in 1858 and centralised in $1960 .^{3}$ Another important actor that may be mentioned is the Swedish Church, which continued controlling the above-mentioned population registration until as late as 1991 (the Swedish Church ceased to be a state church in 2000).

However, the welfare state is no longer in its prime and during recent decades the accepting attitude towards the state has shifted. International developments and instruments regarding individual rights have had an important impact, and a number of cases concerning damages for rights infringements have sparked a development in the courts where stately actors face increasingly strict responsibilities. This is not least the case with regard to the right to privacy and the right to data protection. While the European level of protection has been enhanced with a steadily expanding case law from the European Court of Human Rights (ECtHR) regarding Article 8 of the European Convention on Human Rights (ECHR) and EU law through Articles 7-8 of the EU Charter of Fundamental Rights of the European Union (the Charter) and the GDPR, ${ }^{4}$ a number of "register scandals" have been unearthed in Swedish media. When it comes to the public's knowledge that the Police has an unlawful registry based on ethnicity or that the Swedish Transport Agency has outsourced sensitive information registries to foreign actors without the right competence and security level, the once high level of trust for

\footnotetext{
218 S Census Act (1991:481); SCB webpage, personnumret 70 år (PIN 70 years), www.scb.se/hitta-statistik/artiklar /2017/Personnumret-fyller-70-ar/

SCB webpage, The history of Statistics Sweden, www.scb.se/en/About-us/main-activity/history-of-statistics-sweden/

4 Regulation (EU) 2016/679 of the European Parliament and of the Council of 27 April 2016 on the protection of natural persons with regard to the processing of personal data and on the free movement of such data, GDPR.
} 
the state's personal data collections is tarnished (Chamberlain, 2020, p. 133-136). ${ }^{5}$ The number of personal data incidents reported according to the GDPR's Article 33 has been significant since the regulation was launched, and statistics and analysis show that these incidents often happen in the public sector - not least in a health care context. Around 4,800 incidents were reported during 2019, and just under 4,600 in 2020. The reports analysing them state that a major cause of incidents is when letters or e-mails accidentally are sent to the wrong person, another is undue access. ${ }^{6}$

Another connected, and perhaps yet more important factor to consider is the technical development and digitalisation of society. The system of public registries was established in an altogether different time, when privacy threats posed by the Internet, Big Data and AI did not exist. Today this information - still largely freely available - remains a goldmine for researchers, but also enables everything from data mining and profiling to identity theft and other violations. Once exclusively stately information is profited on by major companies and used in dubious ways by individuals. The question becomes all the more pressing: Is the Swedish tradition of public registries compatible with privacy rights in a digital age?

\section{Background: The Swedish welfare state and social trust - the engineering of a "people's home"}

\subsection{Regulating the welfare state}

There is no comprehensive definition of what is meant by a welfare state and the understanding of the concept varies over time, but today it is often connected to public commitments for social insurance and services (health and care, education, social insurance, labour market measures, etc.) (Edling, 2013, p. 125). The basis for the Swedish welfare state is expressed in Chapter $1, \S 2$ of the Instrument of Government (IG), a Swedish fundamental law:

The personal, economic and cultural welfare of the individual shall be fundamental aims of public activity. In particular, the public institutions shall secure the right to employment, housing and education, and shall promote social care and social security, as well as favourable conditions for good health.

However, the Swedish welfare state is to a large extent a political project, a product of "social engineering" via statutory law, rather than a constitutional right (Lindvall \& Rothstein, 2006, p. 49; Zamboni, 2019, p. 676). The welfare state is thus realised via

\footnotetext{
Apart from the two scandals already mentioned, after a report in 2014 there have been proceedings related to another Police register regarding abused women. Further, in 2019 it was uncovered that millions of telephone calls to the Swedish Health Care Service 1177 had been stored on an unprotected internet server for several years.

6 Datainspektionen, Anmälda personuppgiftsincidenter (rapport 2020:2); Integritetsskyddsmyndigheten, Anmälda personuppgiftsincidenter (rapport 2021:3).
} 
economic and administrative tools, where access to public information has been an important tool. As described by Swedish historian Edling, the formative moment of the Swedish welfare state took place in the 1930s (Edling, 2013, p. 125). While the previous decade was characterised by weak governments, high unemployment rates and industrial conflicts, the 1930s meant the start of a long period of Social Democratic governments (1932 to 1976) and the entrance into a crisis agreement between the Social Democrats and the Farmers' Party, commencing an era of political compromise. During the same decade, the Saltsjöbaden agreement was reached between employers and unions concerning the rules that were to govern labour market relations, laying the foundation of the Swedish labour model. This also led to the rise of corporatism, the strong position of non-governmental organisations in the Swedish society (Edling, 2013, p. 125). It was in this environment that the Social Democratic Party began to build its "people's home", folkhemmet, based on "welfare politics" including an expansive labour market, social reforms and agricultural support (Edling, 2013, p. 126, 139).

From a constitutional perspective, it is interesting to note that this formative moment in Swedish political history took place outside the framework of the IG. The 1809 IG, predecessor to the current 1974 IG, was based on a constitutional system resting on separation of powers. Parliamentarism was introduced in Sweden at the beginning of the $20^{\text {th }}$ century, but without any formal changes to the IG. Not until the late 1960s, and more thoroughly with the enactment of the new 1974 IG, did the written constitution correspond to the actual functioning of the Riksdag (Enzell, 2002, p. 123). This period in time has been characterised as a 'constitution-less half-century', i.e. the constitution was not considered to be part of positive, valid law, but rather a political document not even giving an adequate picture of political life (Sterzel, 2009, p. 13; Taube 2004).

Even though the Swedish welfare state is mainly a political project, the forms for implementing welfare policies is deeply rooted in Swedish constitutional traditions of a strong and partially independent administration, local government and transparency, which will be discussed below (Section 3.1). For this open and decentralised governance structure to function in practice, there is a further prerequisite that is necessary: social trust. As argued by Abrahamsson, the decades immediately following the Second World War were marked by increasing welfare, future optimism and relief that Sweden had escaped the horrors of war, founded on a far-reaching consensus that society's task was not only to ensure the peace and freedom of citizens but also to take overall responsibility for their prosperity and security. It was against this backdrop that the "people's home" was built (Abrahamsson, 2006, p. 413).

\subsection{Social trust}

An important explanatory factor regarding the success of the welfare state in Sweden is social trust. The Swedish society is often described as having a high level of social trust, in that citizens to a large extent trust each other, the government and the public authorities and other institutions in the society (Rothstein, 2020, p. 60). Rothstein holds in 
a paper titled (in translation) "Trustworthy authorities. The foundation of Swedish democracy", that there is a connection between procedural justice, being treated correctly, fairly and equally in encounters with the public administration, and social capital (Rothstein, 2020, p. 62). This can be explained by three factors: that people tend to draw conclusions on the trustworthiness of a society in general based on how they perceive officials, that people who are forced to pay bribes for public services are in general not trustworthy, and that if a person such as yourself has to be dishonest to receive public services, then no one can be trusted (Rothstein, 2020, p. 62). A well-functioning public administration, with fairly competent, honest, professional, merit-based, and unpolitical officials, is thus pivotal to a democratic and peaceful development of the society (Rothstein, 2020, p. 65).

Societal trust plays a function both within the state apparatus, and between the state and the citizens. Trust-based governance in the public administration has been identified as a major aim for the Social Democratic and Green Party Government in power in the late 2010s and early 2020s. ${ }^{7}$ Within the state apparatus, the trustworthiness, impartiality and professionalism of the administration is important for the Government to be able to delegate central tasks (Jacobsson \& Sundström, 2016, p. 13). As is discussed below (Section 3.2), the Swedish administrative model is organised around small government offices and large public authorities at the state level, which is built effectively on the presumption that tasks are delegated. The IG thus favours a decentralised decision-making model in the implementation of policies (Jacobsson \& Sundström, 2016, p. 359 et seq).

In regard to the relation state-individual, a high level of social trust may strengthen the connection between citizens' trust in each other and in societal institutions on the one hand, as well as their willingness to accept what is perceived as a professional and objective measure taken by representatives of the state (Bull, 2013, p. 235). Traditionally, the Swedish public administration has held the trust of the people. Kumlien links this to the court-like features of the public authorities, especially the autonomy of the officials in decision-making and a regulated decision-making procedure including administrative rules on objectivity, a duty on the authority to investigate and a right for individuals to be heard (Kumlien, 2019, p. 215). As pointed out by Lind, the formal side of the rule of law, forms and procedures for decision-making, complements the material character of the welfare state (Lind, 2009, p. 437).

Transparency can in a certain sense be said to be both a consequence and a prerequisite of the trustworthiness of public administration. Transparency allows individuals, market participants, journalists and others an insight into the internal workings of the administration and may function as a preventive measure in combatting maladministration and corruption (Ackerman \& Sandoval-Ballesteros, 2006, p. 92). Transparency and accountability can in themselves foster trust in public administration, which in turn may render individuals more willing to allow the administration to process personal information. As discussed above, the building of a Swedish welfare state is highly interconnected with the building of public archives and registries, providing invaluable

SOU 2018:47 Med tillit växer handlingsutrymmet - tillitsbaserad styrning och ledning av välfärdssektorn. 
information on the recipient of the welfare. From the beginning, tolerance amongst individuals was high for supplying the administration with necessary data. Even if the public mass collection of personal data became more questioned, and also regulated in the 1970s, the Swedes' generally positive attitude to the use of their personal data for the benefit of society remains high, for example in connection to electronic public health records (Rynning, 2007, p. 110). ${ }^{8}$

\section{The function of public information in Sweden - trust in objectivity}

\subsection{Constitutional traditions - decentralisation, autonomy and objectivity}

The organisation of the Swedish executive branch is highly influenced by two specific traits: the semi-autonomous role of the public authorities and the fact that a large part of administrative law - especially issues related to the welfare state - is implemented at the local level, with traditionally strong local self-government. According to the IG, the executive power is highly decentralised via the partially independent public authorities at the national level, Chapter $12, \$ 2$ IG, and strong tradition of local government at the regional and local level, Chapter 14, $\$ 2$ IG. The Swedish administrative model originates from the first half of the $18^{\text {th }}$ century and is thereby of an older date than Swedish parliamentarism (Enzell, 2002, p. 166). It was introduced as a reaction to how the administration had been steered during the previous autocratic era. Authorities are organisationally and legally separated from the Government, regional and municipal councils, respectively, and enjoy a partial independence (Hall, 2016, pp. 300-301). The minister in charge cannot singlehandedly take actions to command and control the public authorities sorting under his or her cabinet, since government decisions must be adopted by the Government collectively, Chapter $7, \S 3$ IG. Further, according to the principle of independence "[n]o public authority, including the Riksdag, or decisionmaking body of any local authority, may determine how an administrative authority shall decide in a particular case relating to the exercise of public authority vis-à-vis an individual or a local authority, or relating to the application of law", Chapter $12, \S 1$ IG. By granting the authorities a sphere of independence, they could only be governed by law and not by decrees in individual cases, separating policy-making and administrative decision-making (Andersson, 2004, p. 38 et seq; Bull, 1999, p. 129).

The local self-government has a long history in Sweden and the present organisation dates back to the municipal reform of $1862 .{ }^{9}$ It may be noted that the Swedish state is organised into three political and administrative levels: national, regional and municipal. Regions and municipalities function under the constitutionally protected principle of local self-government, Chapter $14, \S 2-3$ IG. Implementation of the majority of

SOU 2010:18 Ny biobankslag, p. 242; SOU 2018:4 Framtidens biobanker, p. 276.

SOU 1977:78 Kommunerna: utbyggnad, utjämning, finansiering, pp. 103-104. 
Swedish welfare policies is allocated to the regions and municipalities, which are responsible for, e.g. health care, local public transport, social services, housing and education (in primary and secondary schools).

Public authorities thus hold a strong position in Sweden, and historically there has not been a strict constitutional division between courts and public authorities (Bull \& Sterzel, 2015, p. 259, 275 et seq). It is also notable that the principle of objectivity and impartiality in the IG applies equally to courts and public authorities. Chapter 1, §9 IG reads:

Courts of law, administrative authorities and others performing public administration functions shall pay regard in their work to the equality of all before the law and shall observe objectivity and impartiality.

Further, the principle of transparency and the right to access official documents guarantee insight into public authorities, as documents used in the decision-making process are available to the public (Hirschfeldt, 2017, p. 21). This issue will be discussed next.

\subsection{The supreme value of transparency}

The first Freedom of the Press Act (FPA) was enacted in 1766, whereby a principle of public access to official documents was introduced. The principle of public access to official documents has had a central function in the Swedish constitutional and administrative model, which, as seen above, allows Swedish public authorities partially independent status vis-à-vis the Government. Openness and transparency have played an important role in this context, offering both the parliamentary ombudsman, the press and the public large insight into the internal workings of the administration (Axberger, 2014, p. 105 et seq).

Access to official documents is regulated in Chapter 2, § 2 FPA: "In order to encourage the free exchange of opinion and the availability of comprehensive information and free artistic creation, everyone shall be entitled to have free access to official documents." The reference to the free exchange of opinion and availability of comprehensive information seems to denote a special character of official information as bearer of something vital, which may be explained by the tradition of the FPA being a product of the $18^{\text {th }}$ century enlightenment (Reichel, 2020a, p. 938 et seq).

As will be discussed further in Section 4, the traditions of public archives and registries is closely connected to the principle of access to public documents. Access to official documents may however also be used to provide the public with the means to reveal how public powers work, enhancing the opportunities for holding political actors accountable, combatting corruption and thereby promoting legal certainty and efficiency in legislative, judicial and administrative procedures (Bohlin, 2015, p. 22; Axberger, 2017, p. 256). The value of transparency in Swedish law can in conclusion thereby be seen as a tool for a better-informed public debate and providing better 
conditions for accountability, values also often referred to in literature on transparency in general (Ackerman \& Sandoval-Ballesteros, 2006, p. 87; Gartner, 2013, p. 123; Kingsbury, 2009, p. 25, 48). A trait often further underlined in the Swedish context is that transparency first and foremost is understood as a societal interest and not an individual interest (Lind, 2015, p. 157).

In recent years, the FPA has been under a heated public discussion. The act guarantees a far-reaching right to publish, both in traditional media and online. On the condition that the publisher has a so-called certificate of publication - easy to apply for and granted after just a formal assessment - special rules govern the content of the publication. Censorship is prohibited (Chapter $1, \S 8 \mathrm{FPA}$ ), a very limited crime catalogue applies (including crimes such as treason and defamation; see Chapter 7 FPA), and only the publisher can be held accountable (Chapter $8 \mathrm{FPA}$ ). This means that whoever holds a certificate of publication may publish also sensitive personal data, such as information on someone's criminal records, under the protection of the FPA. As the FPA is seen as superior to the GDPR in the Swedish legal setting, Article 10 GDPR (stating that only public authorities may process such data) is set aside. ${ }^{10}$ The fact that some companies have made a business of publishing not only personal information such as addresses and phone numbers but also criminal records, has in recent years sparked a debate on whether the FPA should be limited in the digital environment of today (see for an in-depth analysis, Österdahl, 2015 p. 83 et seq). In 2018 an exemption was approved regarding systematic and searchable publishing of sensitive personal data on health, ethnicity, etc.: according to Chapter $1, \S 13$ FPA such databases may now be prohibited if they constitute a serious threat to individuals' privacy. The suggested amendment also encompassed personal data relating to criminal records, but this specific issue was postponed due to parliamentarian disagreement. A new governmental survey made another attempt in 2020, followed by a legislative bill in November $2021 .{ }^{11}$ It remains to be seen if legislation on the matter will be passed this time or not.

\section{Registries and archives as tools to develop the welfare state}

\subsection{The tradition of public registries in Sweden}

Sweden has a long tradition of keeping public registries and archives for the benefit of the society at large. Already from the 1530s onwards, the Swedish state began to collect information on an individual level as the basis for tax collection (D'Arcy, Nistotskaya \& Elis, 2015, p. 114). As mentioned above, Sweden National Archives dates back to 1618. Today, the public archives made up of official documents from the public authorities are considered to form a part of the national cultural heritage. ${ }^{12}$ The administrative

\footnotetext{
${ }^{10}$ Chapter $1, \$ 7$ of the Swedish data protection law complementing the GDPR (2018:218).

${ }^{11}$ SOU 2020:45, pp. 268-277; prop. 2021/22:59 Ett ändamålsenligt skydd för tryck- och yttrandefriheten, p. 39-54. Regarding previous attempts to limit the right to publish, see SOU 2012:55 En översyn av tryck- och yttrandefriheten.

12 \3 Archives Act (1990:792); SOU 2019:58, p. 192 et seq.
} 
infrastructure governing how documents are to be collected and stored is governed in detail in the Public Access to Information and Secrecy Act, the Administrative Procedure Act and the Archives Act, which all include rules on when and how information is to be documented, registered and archived, as well as under what conditions a document may be culled. ${ }^{13}$ Special rules may apply for sensitive records. For example, the Social Services Act holds that only a representative sample of social records are to be archived for research purposes (Edquist, 2017, p. 19). ${ }^{14}$ The registries and archives play an essential role in the understanding, planning and further development of the welfare state, in order for the state, regions and municipalities to assess the need for labour market interventions, health care, schools, elderly care, housing, etc. ${ }^{15}$ In regard to sensitive records, for example social services records, only a part of the records are archived. As seen in the introduction, from 1947 and onwards all individuals listed as living in Sweden have been given a unique personal identification number (PIN), which has rendered Swedish registries especially valuable for register-based research (Stenbeck, Eaker Fält \& Reichel, 2021, p. 381). The PIN is used both in relation to public authorities and in the private market.

Today Sweden holds a large number of registries on a wide variety of matters: registries held by police, prisons, tax authorities, authorities within the labour market, housing, health care, schools and more. Further, for use in official statistics, Statistics Sweden holds registries based on data from other public registries, such as the Swedish Tax Agency and the Swedish Social Insurance Agency. The most comprehensive is the register of the total population (RTB), a demographic register that dates back to the 1960s and contains information on birth date, gender and population registration information, such as information about personal relationships. ${ }^{16}$ Statistics Sweden also has other registers that contain information on, for example, the population's education, work, salary, income and remuneration. The University and College Register contains information on students and results in higher education. There are also registries with school students' education, results and grades. ${ }^{17}$ Other authorities hold extensive registries, too. The National Board of health care and welfare holds individual-based registries on social welfare, aid to disabled persons, compulsory care of addicts and children and aid to the elderly. ${ }^{18}$ Both private and public health care institutions collect information

\footnotetext{
${ }^{13}$ Chapters 4-6 Public Access to Information and Secrecy Act (2009:400), \ 27 and $\int 31$ Administrative Procedure Act (1971:291) and \ 4-6 Archival Act. The Archival Act, for instance, regulates how the public authorities are to organise their archives - that is, their collections of public documents. The Act states that archives should be available and accessible so that the constitutional right to access public documents is satisfied, and so that the legal system and researchers can carry out their tasks. Every public authority is responsible for its own archive, except if a special archival authority has assumed this responsibility.

14 Chapter 7, \3 a, Chapter 12, \2 Social Services Act (2001:453).

15 Riksarkivet, Helhetssyn på informationsförsörjning - Riksarkivets perspektiv, 2018-09-27, Dnr RA 04-2017/5870.

${ }^{16}$ Webpage of the Research Council on register-based research, Registries in Sweden, available via www. registerforskning.se.

17 Ibid.

${ }^{18}$ Webpage of the Research Council on register-based research, Social Services Registries, available via www. socialstyrelsen.se. It may be added that it is compulsory for the municipal social services boards to transfer information on individuals to the National Board of Health and Welfare, according to a Government Ordinance on the obligation for the social welfare boards to provide statistical information (1981:1370).
} 
to be included in national quality registries, in order to assess the quality and efficiency of health care. The registries are run by the state and the regions in collaboration and are regulated by an agreement that is updated on a yearly basis. ${ }^{19}$ There are currently just over 100 national quality registers. The registries contain individualised data about medical interventions, procedures and outcomes (Friberg von Sydow, 2017, p. 42). ${ }^{20}$

\subsection{Legal bases and safeguards: Confidentiality and data protection}

As registries began to be operated via digital means in the 1960s, the question of protecting the privacy of the persons registered arose. As noted above, openness is in Swedish law balanced against the interest of privacy for individuals via the Public Access to Information and Secrecy Act. Many registries contain information covered by secrecy under this act and are thereby not available to the public, for example registries within health care, social services, criminal offences, etc. There are however exceptions. Information can be disclosed to researchers and others, under certain conditions set out in the individual case, for example, on confidential treatment.

However, data that in itself can be perceived as relatively harmless may become more sensitive when processed together with large amounts of other categories of personal data, made possible by the Swedish PIN number. Against this background, the Swedish Data Act was enacted in 1973, as the first of its kind in the world at the national level (Chamberlain, 2020, p. 105). The main idea in the Act was to monitor the use of both private and public registries by making them subject to permits issued by a new public authority, the Data Protection Authority. The Data Act was in place until 1998, when it was replaced by the Personal Data Act based on the EU Data Protection Directive, today replaced by the General Data Protection Regulation (GDPR). There is also a corresponding secrecy ground in the Public Access to Information and Secrecy Act, stating that secrecy applies for personal data if it can be assumed that a disclosure would mean that the data would be processed in conflict with the GDPR and certain Swedish legislation implementing the GDPR. ${ }^{21}$ This ground for secrecy has however been interpreted narrowly by the Supreme Administrative Court and has rarely hindered disclosure of personal data held in registries on its own ground, e.g. where no other secrecy ground was applicable (Reichel, 2018).22

Thus, the Swedish public registries are many, and so are the laws and regulations in the area - in fact, they are so many that no one seems to know the exact number! (Öman, 2006, pp. 686-687). ${ }^{23}$ The legislator has thought it best to adapt the register

\footnotetext{
${ }_{19}$ Webpage of the Swedish Association of Local Authorities and Regions, Patientsäkerhet, nationella kvalitetsregister, m.m. 2020, available via https://kvalitetsregister.se

${ }^{20}$ Chapter 7 Patient Data Act (2008:355); Webpage of the Swedish Association of Local Authorities and Regions Quality Registries, available via https://kvalitetsregister.se

${ }^{21}$ Chapter 21, $\int 7$ Public Access to Information and Secrecy Act, referring to the Swedish data protection act complementing the GDPR and \$ 6 Ethical Review Act (2003:460).

${ }^{22}$ Supreme Administrative Court judgment HFD 2021 ref 10.

23 Ds 2000:34 Samhällets grundläggande information, p. 58.
} 
regulation according to the type of information treated and the relevant setting, and therefore there are specialised register laws for most public authorities - for example regarding social services, the Swedish Enforcement Agency and the Swedish Prison and Probation Service. With the entry into force of the GDPR, all regulations were reviewed and, where necessary, revised with explicit rules on legal basis, purpose limitations, available exceptions, etc. ${ }^{24}$ These laws are thus additional to the GDPR and can express both exceptions and stricter conditions. For instance, the population register held by the Tax Authority is regulated by an Act, where the purposes for processing personal data in the registry is defined as coordinated processing, control and analysis of identification data for natural persons and of other population registration data and the handling of population registration matters. ${ }^{25}$ However, further than the purposes listed, the register may also be used for other purposes, as long as they are not incompatible with the purposes for which the data were collected. ${ }^{26}$ This obviously widens the possibilities to use the data considerably. For example, the population registry is used as a basis for the Total Population Register (RTB) held by Statistics Sweden. ${ }^{27}$

A challenge posed by a comprehensive and specialised system such as the Swedish is of course that it makes overarching analysis and coordination difficult. An alternative, harmonised regulation for public registries was suggested in a governmental survey from 2015 , but this option has not yet been followed up. ${ }^{28}$

\section{The role of privacy in connection to public information and official documents}

\subsection{Swedish traditions on the protection of privacy and data protection}

The question of the right to privacy has never had a prominent place in the Swedish legal tradition. Nevertheless, it has been analysed within legal doctrine and in governmental surveys from the 1960s and onwards. There are several reasons for the reluctant Swedish attitude towards the legal protection of privacy. Two important aspects with regards to the topic of this article are: 1 . the strong historical positions of the rights to freedom of expression, freedom of the press and access to public documents; and 2. the trusting attitude of the population towards the stately need for and control of personal information during the establishment and expansion of the welfare state (Abrahamsson, 2006, p. 413).

\footnotetext{
${ }^{24}$ SOU 2017:39 Dataskyddsutredningen.

${ }^{25}$ Chapter 1, $\int 4$ Act on processing personal data in the in the Swedish Tax Agency's population registration activities (2001:182).

26 Ibid.

${ }^{27}$ Webpage of the Research Council on register-based research, The Total Population Register, available via www. registerforskning.se

28 SOU 2015:39 Myndighetsdatalag.
} 
With regards to the first issue, over the years several stately committees have made suggestions to enforce the legal protection of privacy - attempts that have failed due to the potential conflict with our traditional and constitutional principles of access to public information and freedom of the press. For example, the first Privacy Protection Committee (Integritetsskyddskommittén) suggested the introduction of a privacy clause in the criminal catalogue, or a special privacy tort, in its final survey from $1980 .{ }^{29}$ These steps had recently been taken by Norway and Finland. However, this was seen as all too radical in relation to the constitutional principles, and the suggestions were dismissed by the legislator. Instead, the press was encouraged to continue its so-called self-regulation, which entails that newspapers and other media commit to following certain principles and guidelines for publishing - including several paragraphs on privacy intended to minimise and, when appropriate, anonymise any personal information disclosed in the news..$^{30}$ The guidelines for the press can be found at, for example, the website of Journalistförbundet, The Swedish Journalist Association. ${ }^{31}$ Individuals can lodge complaints regarding published information to the Media Ombudsman, who may forward them to the Media Ethical Board. If the Board reaches the conclusion that there has been a wrongful publication, it can issue a reprehension which the newspaper in question must publish. The system has now been established for many decades and is generally considered to be well-functioning.

As seen above (Section 3.2), the question whether processing of sensitive personal data and data on criminal convictions, protected by Articles 9 and 10 GDPR, in publications protected under the FPA have been discussed extensively in the last decade, and some limitations to the right to publish have been made.

Apart from the opposition towards legal privacy protection presented by the constitutional rules, there have been other tendencies during the $20^{\text {th }}$ century which have held back the development. The gigantic project of the welfare state that resulted in a high level of trust with citizens towards the state was discussed above. Accordingly, this social engineering and focus on collective rights meant that rights with an individual dimension like the right to privacy were not in focus during many decades. Even when there are rules protecting privacy, like the Public Access to Information and Secrecy Act, the individual's interest is not emphasised. In a case where public information is not seen as classified, the individual has no possibility to prevent disclosure and no right to appeal such a decision.

Interestingly, when it comes to data protection, the attitude has been decidedly different. During the technical awakening of the 1960s, many people were concerned about new automatic data systems as well as potential intrusions from other individuals through filming and photographing, etc. ${ }^{32}$ This impacted the work of the Privacy Protection Committee and also triggered the enactment of the aforementioned Data Act in 1973 . How come this data protection legislation managed to be passed so early on, when a broader privacy protection is still missing in Swedish law? The answer to this

\footnotetext{
29 SOU 1980:8 Privatlivets fred.

30 SOU 1983:70 Värna yttrandefriheten, p. 251.

31 See specifically concerning privacy, nos 7-10.

32 SOU 1972:47 Data och integritet, p. 41; SOU 1970:47, Skydd mot avlyssning, p. 15.
} 
question seems yet again to lie in the relationship to the constitutional principles of openness, freedom of the press and freedom of expression. All since the negotiations for Sweden's accession to the EU, the Swedish position has been clear: in case of a conflict, the constitutional laws outrule the EU data protection law (Österdahl, 1998, pp. 336-356)..$^{33}$ Even though both the technological development in itself and the European traditions have had an important impact on Swedish law governing registries and archives, the sensitive issue of balancing the right to privacy against the constitutional principles in individual cases is still to be carried out with regard only to Swedish constitutional law.

\subsection{European traditions and the right to rectification and remedies}

In the European setting, data protection has been on the rise since the Council of Europe Convention on personal Data of $1981,{ }^{34}$ followed by the EU Data Protection Directive of $1995,,^{35}$ and the GDPR of 2018. Amongst the fundamental principles of data protection is that the data handled be correct and relevant. The right to privacy is today acknowledged in Article 7 of the Charter, where it is separated from data protection (Article 8). In data protection cases, the Court of Justice of the European Union has referred to both articles in connection. ${ }^{36}$ Article 47 of the Charter states that individuals shall have the right to an effective remedy when their union rights have been infringed.

As with other EU legislation, the focus of the data protection and privacy regulation is largely on effectiveness. Several articles of the GDPR are dedicated to remedies and the right to rectification. In the GDPR, Articles 12-18 and 20-21 regulate the rights of the data subject, for example providing individuals (data subjects) with the right to be informed about and to access their personal data, to demand rectification and erasure. The GDPR does, however, allow for exemptions in relation to both official documents and archives, see Articles 86 and 89.

One of the main features of the GDPR is its focus on remedies for the data subjects. Provisions on remedies and sanctions can be found in Articles 77-84. First, the data subjects have a right to lodge a complaint with a supervisory authority, Article 77 , a right to an effective judicial remedy against binding decisions of the supervisory authorities concerning them, Article 78, and a right to an effective judicial remedy against a controller or processor, Article 79 GDPR. ${ }^{37}$ Further, when misuse of personal data has led to harm, data subjects are entitled to damages according to the provisions of

\footnotetext{
33 Chapter 1, \ 7 Data Protection Act complementing the GDPR.

${ }^{34}$ Convention for the Protection of Individuals with regard to Automatic Processing of Personal Data, ETS 108.

35 Directive 95/46/EC of the European Parliament and of the Council of 24 October 1995 on the protection of individuals with regard to the processing of personal data and on the free movement of such data.

${ }^{36}$ For example C-131/12 Google Spain EU:C:2014:317, para. 69; C-362/14 Schrems I EU:C:2015:650, para. 39.

37 Article 47 Charter further gives a general right to an effective remedy before a tribunal to "everyone whose rights and freedoms guaranteed by the law of the Union are violated".
} 
Article 82 GDPR. Lastly, the supervisory authority may impose administrative fines in a number of situations, Article 83 GDPR.

Another key European legal instrument is the ECHR, where Article 8 lays down the right to respect for private life (and family life, which will not be discussed in this article). The ECHR has had its largest impact in Sweden with regard to Articles 6 and 13 - the right to access to court and to an effective remedy. Together with EU law, the ECHR has prompted Sweden to abandon its century long tradition of administrative review of administrative decisions, replacing it with a general right to access to court (Warnling-Nerep, 2008, p. 45 et seq). Article 13 was also the reason that the Swedish Supreme Court launched its case law on damages based on the ECHR back in $2005 .{ }^{38} \mathrm{In}$ short, the Supreme Court noted that Swedish provisions on non-pecuniary damages meant that certain violations of the ECHR could not be compensated at the national level, which would leave the individual without an effective remedy and thus breach Article 13 ECHR. Therefore, the Supreme Court started ruling that the ECHR may be used as a legal base for such damages claims. This line of case law has since been codified in the Damages Act. ${ }^{39}$

A specific case that has impacted the Swedish development is Segerstedt-Wiberg and others v. Sweden, where the ECtHR ruled that the Data Protection Authority and Registry Board were not sufficient as effective remedies..$^{40} \mathrm{In}$ the case, the personal data of a number of individuals had been secretly registered for political reasons, and stored for lengthy amounts of time. The court considered that the information recorded was disproportionate when balanced against the necessity of the data storage, and that Sweden therefore was in breach of Article 8 ECHR regarding all but one applicant. ${ }^{41}$ The data subjects had not had access to a remedy where they could demand erasure of their personal data, which the Court deemed problematic. As a result of the judgment, a new Swedish authority was created which enabled individuals to initiate a process of scrutiny and erasure, the Swedish Commission on Security and Integrity Protection, and the competence of the Chancellor of Justice was expanded. In a later case, Eriksson $v$. Sweden, the ECtHR ruled that Sweden now could be considered to have satisfactory and effective remedies according to Article 13 ECHR.42 There are also examples of ECtHR ruling where Sweden's positive obligations regarding Article 8 have been regarded as unfulfilled - which has led to amendments of national legislation to strengthen the privacy protection. ${ }^{43}$

\footnotetext{
${ }_{38}$ See for instance NJA 2005, p. 462, NJA 2007, p. 584 and NJA 2012, p. 211 I-II.

39 Chapter 3, \4 and Chapter 5, \8 Damages Act (1972:207), preparatory work prop 2017/18:7.

40 Segerstedt-Wiberg and others v. Sweden (Appl. no. 62332/00), judgment of 6 June 2006.

${ }^{41}$ Ibid. Para. 87-92.

${ }^{42}$ Eriksson v. Sweden (Appl. no. 60437/08), judgment of 12 April 2012.

43 Söderman v. Sweden [GC] [Appl. no. 5786/08], judgment of 12 November 2013 and the Swedish criminalisation of offensive photographing in Chapter 4, $₫ 6$ a of the Criminal Code (1962:700), which happened just a few months before the judgment from the ECtHR.
} 


\subsection{Remedies in Swedish law}

Considering the massive amount of personal data constantly handled by the public authorities, it is not surprising that mistakes sometimes occur. For example, the data registered can be incorrect - which causes the individual administrative difficulties, and sometimes pecuniary or (most often) non-pecuniary harm.

As seen above, Swedish law has had a complicated relationship to European traditions on privacy, not least in relation to rules on transparency and official documents (Österdahl, 2015, p. 74). In practice, Swedish law has made wide use of the exemptions in Articles 86 and 89 GDPR in relation to access to documents and archives, even declaring that the GDPR is not to be applied in the sphere of application of the FPA. ${ }^{44}$ This also relates to remedies (Reichel, 2020b, p. 125). Thus, a data subject cannot appeal a decision to release an official document including his or her personal data, nor appeal a decision refusing to cull such documents from an archive. ${ }^{45}$ Further, the personal information covered by Article $8 \mathrm{ECHR}$ does not in itself constitute grounds for secrecy. ${ }^{46}$

However, certain general adjustments have been made to accommodate European requirements in relation to the right to remedies, which may be applicable also in this area. Since the right to appeal administrative decisions where personal data of a data subject are processed in official documents is closed on a general level, these alternative remedies may thus be used. In cases where data protection rights have been breached, the data subject can lodge a complaint with the Data Protection Authority or the Swedish Commission on Security and Integrity Protection, which may lead to a process of investigation and ultimately criticism of the public authority in question. As seen above, if there has been a breach of the GDPR, administrative fines according to Article 83 could also be imposed. If the individual has experienced harm, Article 82 GDPR can be used to claim compensation, and if the state is the defendant, a damages claim can be made through the Chancellor of Justice. This does not cost the individual anything and is an alternative to taking the case to court. Often the process is smooth and relatively fast, and following the large number of decisions in the area certain levels of compensation have been outlined throughout the years, which makes the legal situation predictable for the individual (see Chamberlain, 2020, pp. 367-375, for an overview and analysis of these decisions). However, the amounts paid within this system cannot be described as high - particularly not when compared to the administrative fines.

\section{Is the state still trustworthy?}

In the long history of Swedish personal data registries, big changes have taken place over the last few decades. This development is of course closely connected to technological advancements and the resulting changed legal requirements, as well as to

\footnotetext{
${ }^{44}$ Chapter 1, \ 7 Data Protection Act complementing the GDPR.

45 Chapter 2, \$ 19 FPA and Supreme Administrative Court judgment HFD 2015 ref 71.

46 Supreme Administrative Court judgment RÅ 2006 ref 87.
} 
Europeanisation. The Swedish cultural heritage of accessible archives and public information must now be viewed in light of obligations following the ECtHR case law and EU law, such as the right to remedies for informational privacy intrusions and the requirements of the GDPR to balance the interest of transparency and the keeping of archives with the rights of the individual. ${ }^{47}$

Information that was originally public but manually organised and stored in libraries or archives can today (intentionally or sometimes unintentionally) become public online, all in a matter of seconds. The phenomenon of expanding data protection regulations and digitalisation create much tension in the relationship between the traditional public interest of collecting data and the evolving rights of individual data subjects. Through the unearthing of various register scandals and the thousands of personal data incidents reported within the GDPR system each year, it has become obvious that the register holders - be they public or private entities - often fail to maintain control over sensitive personal data. This necessarily impacts the level of social trust when it comes to the Swedes' sharing of information. Furthermore, personal data that is easily accessible due to the constitutional principles of transparency is used illicitly by other individuals for purposes of fraud through identity theft and the like, as well as for intrusive marketing and profiling.

What should be done to answer to these challenges? First, the administration must update its data security and ensure sufficient resources to ensure that the data kept in archives and registries is safe. This seems to require political will, budgetary priorities and well-trained staff, rather than merely legal tools.

Secondly, the legal development cannot rest - despite several important steps having been taken by the legislator in recent years. A much-needed amendment was the criminalisation of identity theft and spreading of sensitive images, which after decades of debate took place just a few years back. ${ }^{48}$ As mentioned above, offensive photographing was criminalised in 2013. ${ }^{49}$ These updates also enable victims to file for damages as compensation for economic and non-pecuniary losses. As seen above, the legal remedies available for individuals in cases related to data protection and privacy rights have been strengthened after international pressure.

Although these changes may seem promising, they are not without loopholes. The new paragraph on spreading of sensitive images is not applicable in the constitutionally protected area of publishing, and the possibilities of online publishing regarding detailed personal data such as home addresses and telephone numbers, birthday dates and living conditions, remain far-reaching. To a large extent, these personal data are not covered by secrecy under the Public Access to Information and Secrecy Act, and the online publishing of data relating to criminal offences has not yet been prohibited. As seen above, when the publisher has a certificate of publication, the publication is

\footnotetext{
47 See in regard to the latter C-439/19 B EU:C:2021:504, para 120.

${ }^{48}$ Chapter 4, \ 6 b of the Criminal Act regarding identity theft, implemented in 2016, and Chapter 4, \ $6 \mathrm{c}$ regarding privacy invasions by spreading sensitive information, passed in 2017.

49 Chapter 4, \$ 6 a Criminal Act.
} 
protected under the FPA and the GDPR is not deemed applicable. This goes back on the abovementioned constitutional rules on transparency and freedom of information, which would need to be adapted - or at least complemented with exceptions - to limit and control what happens with personal data collected by for example the Tax Agency.

The obvious clash between the Swedish reality when it comes to the handling of personal data and GDPR principles on for example purpose limitation is thus explained by the Swedish attitude to the hierarchy between EU regulations and Swedish constitutional law. There is a danger in this stubborn denying of the necessity to modernise and nuance legislation. In all certainty, the prospect for our fundamental constitutional principles to continue to thrive builds on the willingness to develop them according to today's conditions and specifically our digital society. If the legislator refuses to do so, the social trust of the welfare state may soon be altogether consumed.

\section{References}

Abrahamsson, O. (2006). Integritetsskyddet i lagstiftningen. Svensk Juristtidning, pp. 410-424.

Ackerman, J. M. \& Sandoval-Ballesteros, I. E. (2006). The Global Explosion of Freedom of Information Laws. Administrative Law Review, 58(1), 85-130. Online: https://bit.ly/31blx1P

Andersson, C. (2004). Tudelad trots allt: dualismens överlevnad i den svenska staten 1718-1987.

Statsvetenskapliga institutionen, Stockholms universitet.

Axberger, H.-G. (2014). JO - i riksdagens tjänst. Elanders.

Axberger, H.-G. (2017). Yttrandefrihetsgrundlagarna ( $3^{\text {rd }}$ edition). Wolters Kluwer.

Axberger, H.-G. (2020). Rättigheter I. Svensk Juristtidning, pp. 759-786.

Bohlin, A. (2015). Offentlighetsprincipen ( $8^{\text {th }}$ edition). Stockholm: Norstedts förlag.

Bull, T. (1999). Självständighet och pluralism - om vertikal maktdelning i Sverige. In L. Marcusson (Ed.), Festskrift till Fredrik Sterzel (pp. 107-133). Iustus.

Bull, T. (2013). Global governance; need for a new theory or the return of an old friend? In A.-S. Lind \& J.

Reichel (Eds.), Administrative law beyond the state: Nordic Perspectives (pp. 230-239). Nijhoff Publishers.

Bull, T. \& Sterzel, F. (2015). Regeringsformen: En kommentar ( $3^{\text {rd }}$ edition). SNS förlag.

Chamberlain, J. (2020). Integritet och skadestånd: Om skyddet för personuppgifter och privatliv i svensk rätt. Iustus.

D’Arcy, M., Nistotskaya, M. \& Elis, R. (2015). State-building, democracy and taxation: Why Ireland will never be Sweden. University of Tokyo Journal of Law and Politics, 12(Summer), 110-123.

Edquist, S. (2017). Ethical Destruction? Privacy concerns regarding Swedish social services records. In P. Jonason \& A. Rosengren (Eds.), The Right to access to information and the right to privacy. A democratic balancing act (pp. 11-39). Södertörns högskola.

Edling, N. (2013). The Primacy of Welfare Politics. Notes on the language of the Swedish Social Democrats and their adversaries in the 1930s. In H. Haggrén, J. Rainio-Niemi \& J. Vauhkonen (Eds.), Multi-layered Historicity of the Present: Approaches to Social Science History (pp. 125-150). University of Helsinki.

Enzell, M. (2002). Requiem for a Constitution: Constitutionalism and Political Culture in Early $20^{\text {th }}$ Century Sweden. Stockholm University.

Friberg von Sydow, R. (2017). Medical Records - the different Data Carriers Used in Sweden from the End of the $19^{\text {th }}$ Century Until Today and Their Impact on Confidentiality, Integrity and Availability. In P. Jonason \& A. Rosengren (Eds.), The Right to Access to Information and the Right to Privacy. A democratic balancing act (pp. 41-60). Södertörns högskola. 
Gartner, D. (2013). Uncovering Bretton Woods: Conditional Transparency, the World Bank, and the International Monetary Fund. George Washington International Law Review, 45, 121-148.

Hall, P. (2016). The Swedish Administrative Model. In J. Pierre (Ed.), The Oxford Handbook of Swedish Politics (pp. 299-314). Online: https://doi.org/10.1093/oxfordhb/9780199665679.013.17

Hirschfeldt, J. (2017). Free Access to Public Documents - A Heritage From 1766. In A.-S. Lind, J. Reichel \& I. Österdahl (Eds.), Transparency in the Future - Swedish Openness 250 Years (pp. 21-28). Ragulka.

Jacobsson, B. \& Sundström, G. (2016). Governing the State. In J. Pierre (Ed.), The Oxford Handbook of Swedish Politics (pp. 348-362). Online: https://doi.org/10.1093/oxfordhb/9780199665679.013.20

Kingsbury, B. (2009). The Concept of 'Law' in Global Administrative Law. The European Journal of International Law, 20(1), 23-57. Online: https://doi.org/10.1093/ejil/chp005

Kumlien, M. (2019). Professorspolitik och samhällsförändring. En rättshistorisk undersökning av den svenska förvaltningsrättens uppkomst. Stockholm: Institutet för rättshistorisk forskning.

Lind, A.-S. (2009). Sociala rättigheter i förändring: En konstitutionellrättslig studie. Iustus.

Lind, A.-S. (2015). Sweden: Free Press as a First Fundamental Right. In M. Suksi, M. Nowak, K. AgapiouJosephides \& J.-P. Lehners (Eds.), First Fundamental Rights Documents in Europe. Commemorating 800 Years of Magna Carta (pp. 151-162). Intersentia. Online: https://doi.org/10.1017/9781780685281.013

Lindvall, J. \& Rothstein, B. (2006). Sweden: The Fall of the Strong State. Scandinavian Political Studies, 29(1), 47-63. Online: https://doi.org/10.1111/j.1467-9477.2006.00141.x

Öman, S. (2006). Särskilda registerförfattningar. In C. Magnusson Sjöberg \& P. Wahlgren (Eds.), Festskrift till Peter Seipel (pp. 685-705). Norstedts juridik.

Österdahl, I. (1998). Openness v. Secrecy: Public Access to Documents in Sweden and the European Union. European Law Review, 23(4), 336-356.

Österdahl, I. (2015). Transparency versus secrecy in an international context: a Swedish dilemma. In A.-S. Lind, J. Reichel \& I. Österdahl (Eds.), Information and Law in Transition: Freedom of Speech, the Internet, Privacy and Democracy in the $21^{\text {st }}$ Century (pp. 74-99). Liber.

Reichel, J. (2018). Public Access or Data Protection as a Guiding Principle in the EU's Composite Administration? An Analysis of the ReNEUAL Model Code in the Light of Swedish and European Case law. In P. Wahlgren (Ed.), 50 Years of Law and IT (pp. 285-308). Jure.

Reichel, J. (2020a). Transparency and Openness. In P. Cane, H. C. H. Hofmann, E. C. Ip \& P. L. Lindseth (Eds.), The Oxford Handbook of Comparative Administrative Law (pp. 935-956). Oxford University Press. Online: https://doi.org/10.1093/oxfordhb/9780198799986.013.52

Reichel, J. (2020b). What is it the public has a right to know? The right to privacy for public officials and the right of access to official documents - European and Swedish perspectives. In A. Koltay \& P. Wragg (Eds.), Comparative Privacy and Defamation: Research Handbook in Comparative Law (pp. 112-129). Edward Elgar Publishing. Online: https://doi.org/10.4337/9781788970594.00014

Rothstein, B. (2020). Myndigheter att lita på. Den svenska demokratins grundbult. In L. Sandström \& C. Peterson (Eds.), Den svenska förvaltningsmodellen (pp. 44-77). Institutet för rättshistorisk forskning.

Rynning, E. (2007). Public Trust and Privacy in Shared Electronic Health Records. European Journal of Health Law, 14(2), 105-112. Online: https://doi.org/10.1163/092902707X211668

Stenbeck, M., Eaker Fält, S. \& Reichel, J. (2021): Swedish law on personal data in biobank research: permissible but complex. In S. Slokenberga, O. Tzortzatou \& J. Reichel (Eds.), Individual Rights, the Public Interest and Biobank Research - Article 89 GDPR and European Legal Responses (pp. 379-394). Springer International. Online: https://doi.org/10.1007/978-3-030-49388-2_21

Sterzel, F. (2009). Författning i utveckling: Tjugo studier kring Sveriges författning ( $2^{\text {nd }}$ edition). Iustus.

Taube, C. (2004). Regeringsformen: positiv rätt eller redskap för rättshaverister? In E. Smith \& O. Petersson (Eds.), Konstitutionell demokrati (pp. 42-70). SNS förlag.

Warnling-Nerep, W. (2008). Rätten till domstolsprövning och rättsprövning ( $3^{\text {rd }}$ edition). Stockholm Jure. Zamboni, M. (2019). The Positioning of the Supreme Courts in Sweden - A Democratic Oddity? European Constitutional Law Review, 15(4), 668-690. Online: https://doi.org/10.1017/S1574019619000361 